Correspondence

Hanna Pituch

hanna.pituch@wum.edu.pl

Received 4 January 2011

Accepted 14 March 2011

\section{Characterization and antimicrobial susceptibility of Clostridium difficile strains isolated from adult patients with diarrhoea hospitalized in two university hospitals in Poland, 2004-2006}

\author{
Hanna Pituch, ${ }^{1}$ Piotr Obuch-Woszczatyński, ${ }^{1}$ Dorota Wultańska, ${ }^{1}$ \\ Grażyna Nurzyńska, ${ }^{2}$ Celine Harmanus, ${ }^{3}$ Aleksandra Banaszkiewicz, ${ }^{4}$ \\ Andrzej Radzikowski, ${ }^{4}$ Mirosław Łuczak, ${ }^{1,2}$ Alex van Belkum ${ }^{5}$ \\ and Ed Kuijper ${ }^{3}$
}

\author{
${ }^{1}$ Department of Medical Microbiology, Medical University of Warsaw, 5 Chałubiński Street, 02-004 \\ Warsaw, Poland \\ ${ }^{2}$ Central Public Hospital, Medical University of Warsaw, $1 \mathrm{~A}$ Banacha Street, Warsaw, Poland \\ ${ }^{3}$ Reference Laboratory for Clostridium difficile, Department of Medical Microbiology L-1, Leiden \\ University Medical Center, Albinusdreef 2, 2333 ZA Leiden, The Netherlands \\ ${ }^{4}$ Department of Pediatric Gastroenterology and Nutrition, Medical University of Warsaw, 1/3 \\ Działdowska Street, Warsaw, Poland \\ ${ }^{5}$ bioMérieux 3, Route de Port Michand, 38390 La Balme les Grottes, France
}

\begin{abstract}
This study analysed 330 Clostridium difficile strains isolated from patients with C. difficile infection who were hospitalized in two university hospitals $(\mathrm{H} 1$ and $\mathrm{H} 2)$ in Warsaw, Poland, over the period 2004-2006. Strains were investigated for the presence of $t c d A(A), t c d B(B)$ and binary toxin (CDT) genes, and antimicrobial susceptibility was determined against nine agents. Among the $330 \mathrm{C}$. difficile isolates, 150 (45.4\%) were classified as $\mathrm{A}^{+} \mathrm{B}^{+} \mathrm{CDT}^{-}, 18(5.5 \%)$ as $\mathrm{A}^{+} \mathrm{B}^{+} \mathrm{CDT}^{+}, 144(43.6 \%)$ as $\mathrm{A}^{-} \mathrm{B}^{+} \mathrm{CDT}^{-}$and 18 (5.5\%) as $\mathrm{A}^{-} \mathrm{B}^{-} \mathrm{CDT}^{-}$. The predominant PCR ribotype in hospitals $\mathrm{H} 1$ and $\mathrm{H} 2$ was type 017 and accounted for 48.3 and $40.0 \%$, respectively. Only one PCR ribotype 027 strain was found. The rates of resistance to erythromycin and clindamycin in hospitals $\mathrm{H} 1$ and $\mathrm{H} 2$ were 53.6 and $53.6 \%$, and 48.6 and $47.5 \%$, respectively, whereas resistance rates to the newer fluoroquinolones gatifloxacin and moxifloxacin were 38.5 and $38.5 \%(\mathrm{H} 1)$ and 38.4 and $40.1 \%(\mathrm{H} 2)$. Erythromycin resistance was frequently associated with resistance to clindamycin and newer fluoroquinolones in strains belonging to type 017 . No metronidazole- and vancomycin-resistant isolates were found, although two C. difficile isolates had elevated MIC values of metronidazole (MIC range $1.0-1.5 \mathrm{mg} \mathrm{I}^{-1}$ ) and 15 strains revealed elevated MIC values for vancomycin (MIC range 1.5-2.0 $\mathrm{mg} \mathrm{I}^{-1}$ ). In conclusion, an increase in non-027 CDT-producing C. difficile strains was observed in Poland, but C. difficile PCR ribotype 017 remains a major circulating type.
\end{abstract}

\section{INTRODUCTION}

Clostridium difficile is a major cause of antibioticassociated diarrhoea in hospitalized patients (Freeman et al., 2010). Toxigenic isolates usually produce two toxins: toxin $\mathrm{A}(\mathrm{A})$ and toxin $\mathrm{B}(\mathrm{B}) \cdot \mathrm{A}^{-} \mathrm{B}^{+}$strains do not produce detectable amounts of toxin $A$ due to a deletion in the repeating sequence of the $t c d A$ gene encoding the toxin (Kato et al., 1998). Some C. difficile strains produce a third

Abbreviations: CDI, Clostridium difficile infection; CDT, binary toxin; CLSI, Clinical and Laboratory Standards Institute. additional toxin, called $C$. difficile binary toxin (CDT), which can enhance the attachment of $C$. difficile to intestinal epithelial cells (Schwan et al., 2009). Since 2003, outbreaks of $C$. difficile infection (CDI) due to an emerging strain of PCR ribotype 027 possessing CDT and resistant to erythromycin and/or clindamycin and newer fluoroquinolones have been reported in North America and Europe (Loo et al., 2005; Kuijper et al., 2008; Clements et al., 2010). This strain has a point mutation in $t c d C$, a putative negative regulator of toxins A and B (Spigaglia \& Mastrantonio, 2002; McDonald et al., 2005). 
The most commonly used drugs for the treatment of CDI are metronidazole and vancomycin. However, some $C$. diffficile isolates have elevated MICs for metronidazole (MIC $32 \mathrm{mg} \mathrm{l}^{-1}$ ) and vancomycin (MIC $16 \mathrm{mg} \mathrm{l}^{-1}$ ) (Peláez et al., 2002), although the clinical significance is not clear yet.

The aim of this study was to characterize $330 \mathrm{C}$. difficile strains isolated from adult patients with diarrhoea hospitalized in two university hospitals over the period 2004-2006. Additionally, MICs of nine different antimicrobial agents were determined.

\section{METHODS}

Hospitals. Two university-associated hospitals with regional and national reference functions for specialized care participated in this surveillance study. The hospitals are located in Warsaw, Poland: the Infant Jesus Teaching Hospital, assigned as H1 ( $n=675$ beds; 12 clinics), and the Public Hospital of the Medical University of Warsaw, assigned as H2 ( $n=1177$ beds; 16 clinics). Only faeces samples were included from patients with diarrhoea from whom the physician requested a diagnostic test for CDI. Diagnosis of CDI was based on a positive stool ELISA result using the $C$. difficile TOX A/B II kit (TechLab) for detection of toxin $\mathrm{A}$ and/or toxin $\mathrm{B}$ and on the isolation of toxigenic C. difficile strains over the period 2004-2006.

Micro-organisms. A total of 330 clinical C. difficile strains isolated from patients hospitalized between 2004 and 2006 in hospitals H1 $(n=153)$ and H2 $(n=177)$ were available for detailed characterization. In hospital $\mathrm{H} 1$, isolates were obtained from the following wards: general surgery $(n=39)$, internal medicine $(n=35)$, transplantation $(n=33)$, orthopaedics $(n=12)$, intensive care $(n=10)$, urology $(n=9)$, dermatology $(n=6)$, gynaecology $(n=1)$ and several other wards $(n=8)$. In hospital $\mathrm{H} 2$, isolates were obtained from the following wards: haematology $(n=55)$, gastrointestinal surgery $(n=30)$, neurology $(n=16)$, nephrology $(n=14)$, vascular surgery $(n=10)$, general surgery $(n=7)$, neurosurgery $(n=7)$, internal medicine $(n=5)$, haematological intensive care $(n=5)$, cardiac surgery $(n=4)$, endocrinology $(n=4)$, pulmonology $(n=4)$, dialysis $(n=2)$, thoracic surgery $(n=2)$, neurological intensive care $(n=1)$, cardiology $(n=1)$ and several other wards $(n=10)$. All isolates were stored at $-70{ }^{\circ} \mathrm{C}$ and were sent to the Department of Medical Microbiology (hospital H1) for further characterization and determination of susceptibility to nine antimicrobial agents. Isolation of $C$. difficile was performed on selective Columbia agar supplemented with cycloserine/cefoxitin and amphotericin B (CLO medium; bioMérieux). The plates were incubated in an anaerobic chamber for $48 \mathrm{~h}$ at $37^{\circ} \mathrm{C}$. Isolates were identified as $C$. difficile by the characteristic morphology of the colonies and horse-like odour, green-yellow fluorescence under UV light $(365 \mathrm{~nm})$, Gram staining and an API 20A biochemical test (bioMérieux). Three reference strains were included in this study as controls: toxigenic C. difficile VPI $10463\left(\mathrm{~A}^{+} \mathrm{B}^{+}\right)$, non-toxigenic $C$. difficile NIHBRRIGS $8050\left(\mathrm{~A}^{-} \mathrm{B}^{-}\right)$and $C$. difficile GAI 95601 $\left(\mathrm{A}^{-} \mathrm{B}^{+}\right.$) (from H. Kato, Institute of Anaerobic Bacteriology, Gifu University School of Medicine, Gifu, Japan). CDT-producing control strains were provided by Jon Brazier (Anaerobe Reference Laboratory, Cardiff, UK) and Ed Kuijper (Leiden University Medical Center, Leiden, The Netherlands) and consisted of R8637 (PCR ribotype 019), R5989 (PCR ribotype 023), R10456 (PCR ribotype 056) and strains from PCR ribotypes 045, 078 and 027.

Determination of toxin genes. PCRs to detect the $t c d A$ and $t c d B$ genes and deletions in the $t c d A$ gene were conducted as described previously (Pituch et al., 2006). Primers described by Stubbs et al. (2000) were used for amplification of the CDT genes $c d t A$ and $c d t B$, as described previously (Pituch et al., 2006). Amplification and sequencing of the $t c d C$ gene was also performed to investigate the presence of deletions in this gene.

PCR ribotyping. $C$. difficile CDT gene-positive $(n=18)$ and $\mathrm{A}^{-} \mathrm{B}^{+} \mathrm{CDT}^{-}$isolates $(n=144)$ were typed by PCR ribotyping as described by Stubbs et al. (1999). Banding patterns were compared with those of the library of PCR ribotypes at the Anaerobe Reference Laboratory, Cardiff, UK.

Antimicrobial drug susceptibility testing. MICs of a panel of seven antimicrobial drugs were determined against the 330 C. difficile isolates using Etest strips (AB Biodisk) with exponential gradients of antimicrobial concentrations of $0.016-256.0 \mathrm{mg} \mathrm{l}^{-1}$ : erythromycin, clindamycin, metronidazole, vancomycin, ciprofloxacin, gatifloxacin and moxifloxacin. In addition, 100 randomly selected $C$. difficile isolates from hospital $\mathrm{H} 1$ and 164 from hospital $\mathrm{H} 2$ were tested against imipenem $\left(0.002-32.0 \mathrm{mg} \mathrm{l}^{-1}\right)$, and 100 isolates from $\mathrm{H} 1$ and 133 from $\mathrm{H} 2$ were tested against tetracycline $\left(0.002-32.0 \mathrm{mg} \mathrm{l}^{-1}\right)$. Cultures were adjusted to an $\mathrm{OD}_{950}$ of 1 (using a bioMérieux ATB1550 densitometer) on the McFarland scale, and streaked and grown to confluency on the surface of Brucella agar plates. Plastic strips with the antibiotics were applied and the plates were incubated anaerobically at $37{ }^{\circ} \mathrm{C}$ for $48 \mathrm{~h}$. According to the Clinical and Laboratory Standards Institute (CLSI) recommendations (CLSI, 2007), antibiotic resistance was defined as follows: MIC $\geqslant 8.0 \mathrm{mg}$ $1^{-1}$ for clindamycin and erythromycin, MIC $\geqslant 32.0 \mathrm{mg}^{-1}$ for metronidazole, MIC $\geqslant 32 \mathrm{mg} \mathrm{l}^{-1}$ for vancomycin, MIC $\geqslant 4 \mathrm{mg} \mathrm{l}^{-1}$ for ciprofloxacin, gatifloxacin and moxifloxacin, and MIC $\geqslant 16 \mathrm{mg}$ $1^{-1}$ for imipenem and tetracycline. Quality-control strains (Bacteroides fragilis NCTC 11295, Bacteroides thetaiotaomicron ATCC 29741, Escherichia coli ATCC 25922 and Staphylococcus aureus ATCC 25923) were always included. A $688 \mathrm{bp}$ fragment of the ermB gene for erythromycin resistance was amplified using specific primer pairs 2980 (5'-AATAAGTAAACAGGTAACGTT-3') and 2981 (5'GCTCCTTGGAAGCTGTCAGTAG-3') (Johnson et al., 1999). PCR cycling conditions comprised 30 cycles of $60 \mathrm{~s}$ at $95{ }^{\circ} \mathrm{C}, 120 \mathrm{~s}$ at $55^{\circ} \mathrm{C}$ and $180 \mathrm{~s}$ at $72{ }^{\circ} \mathrm{C}$.

\section{RESULTS}

\section{Characterization of $\mathbf{C}$. difficile strains}

Between 2004 and 2006, we characterized 330 C. difficile strains collected in two hospitals in Warsaw. Overall, 150 isolates $(45.4 \%)$ were classified as $\mathrm{A}^{+} \mathrm{B}^{+} \mathrm{CDT}^{-}, 144$ (43.6\%) were $\mathrm{A}^{-} \mathrm{B}^{+} \mathrm{CDT}^{-}$(Table 1$)$ and $18(5.5 \%)$ were $\mathrm{A}^{+} \mathrm{B}^{+} \mathrm{CDT}^{+}$. Of 312 C. difficile isolates designated $\mathrm{A}^{+} \mathrm{B}^{+} \mathrm{CDT}^{-}, \mathrm{A}^{-} \mathrm{B}^{+} \mathrm{CDT}^{-}$or $\mathrm{A}^{+} \mathrm{B}^{+} \mathrm{CDT}^{+}$, $\mathrm{PCR}$ amplification with primer pairs YT28/YT29 and YT17/YT18 (Pituch et al., 2006) generated products of 630 and 399 bp for the $t c d A$ and $t c d B$ genes, respectively. PCR to detect deletion of repeat sequences in the $t c d A$ gene with the NK9/ NKV011 (Pituch et al., 2006) primer pair for the 144 $\mathrm{A}^{-} \mathrm{B}^{+} \mathrm{CDT}^{-}$strains generated a $700 \mathrm{bp}$ product similar to that obtained for the Japanese GAI 95601 C. difficile strain and for the prevalent group of $\mathrm{A}^{-} \mathrm{B}^{+}$strains of $\mathrm{PCR}$ ribotype 017 . The remaining $18 \mathrm{C}$. difficile isolates $(5.5 \%)$ were $\mathrm{A}^{-} \mathrm{B}^{-} \mathrm{CDT}^{-}$. The distribution of $C$. difficile toxigenicity profiles was comparable for hospitals $\mathrm{H} 1$ and $\mathrm{H} 2$ (Table 1). 
Table 1. Summary of toxigenicity profiles of $330 \mathrm{C}$. difficile strains isolated from patients with diarrhoea in two university hospitals $(\mathrm{H} 1$ and $\mathrm{H} 2)$ in Warsaw between 2004 and 2006

\begin{tabular}{|lcc|}
\hline Toxigenicity profile & H1 $(\boldsymbol{n}=\mathbf{1 5 3})$ & $\mathbf{H 2}(\boldsymbol{n}=\mathbf{1 7 7})$ \\
\hline $\mathrm{A}^{+} \mathrm{B}^{+} \mathrm{CDT}^{-}$ & $62(40.5 \%)$ & $88(49.7 \%)$ \\
$\mathrm{A}^{+} \mathrm{B}^{+} \mathrm{CDT}^{+}$ & $8(5.3 \%)$ & $10(5.6 \%)$ \\
$\mathrm{A}^{-} \mathrm{B}^{+} \mathrm{CDT}^{-}$ & $74(48.3 \%)$ & $70(39.6 \%)$ \\
$\mathrm{A}^{-} \mathrm{B}^{-} \mathrm{CDT}^{-}$ & $9(5.9 \%)$ & $9(5.1 \%)$ \\
\hline
\end{tabular}

PCR ribotyping of the $18 \mathrm{CDT}^{+}$strains found that only one strain showed the same pattern as the control 027 strains. The remaining $\mathrm{CDT}^{+}$strains showed patterns similar to ribotype $023(n=16)$ and ribotype $045(n=1)$. All 144 isolates producing toxin $\mathrm{B}$ only $\left(\mathrm{A}^{-} \mathrm{B}^{+} \mathrm{CDT}^{-}\right)$recovered from hospitals $\mathrm{H} 1$ and $\mathrm{H} 2$ belonged to ribotype 017 .

\section{Antimicrobial susceptibility}

Overall, the C. difficile isolates showed some resistance to seven of the nine antimicrobial agents tested (Tables 2 and 3). All 330 C. difficile strains were susceptible to metronidazole (MIC range $0.016-1.5 \mathrm{mg} \mathrm{l}^{-1}$ ) and vancomycin (MIC range $0.023-2.0 \mathrm{mg} \mathrm{l}^{-1}$ ), according to CLSI breakpoints. Two strains had elevated MIC values for metronidazole ( 1.0 and $1.5 \mathrm{mg} \mathrm{l}^{-1}$ ) and 15 strains had elevated MIC values for vancomycin (1.5-2.0 $\mathrm{mg} \mathrm{l}^{-1}$ ). Of the two isolates with elevated MICs for metronidazole, one isolate originated from the dermatology ward $(\mathrm{H} 1)$ and one from the haematology ward (H2). Six of the C. difficile isolates with elevated MICs for vancomycin originated from patients hospitalized in $\mathrm{H} 1$ in surgery $(n=3)$, dermatology $(n=2)$ and cardiology intensive care $(n=1)$, whilst the remaining nine isolates were obtained from patients hospitalized in $\mathrm{H} 2$ in nephrology $(n=2)$, vascular surgery $(n=2)$, internal medicine $(n=1)$, haematology $(n=1)$, gastrointestinal surgery $(n=1)$, neurosurgery $(n=1)$ and general surgery $(n=1)$. In total, $163(49.4 \%)$ of the 330 C. difficile isolates were cross-resistant to erythromycin and clindamycin. Of these, $52.3 \%(n=80)$ were from $\mathrm{H} 1$ and $46.9 \%(n=83)$ were from $\mathrm{H} 2$. Among the $\mathrm{A}^{-} \mathrm{B}^{+} \mathrm{CDT}^{-} C$. difficile strains isolated in $\mathrm{H} 1$ and $\mathrm{H} 2,68(91.9 \%)$ and 63 strains $(90.0 \%)$, respectively, were cross-resistant to erythromycin and clindamycin and harboured the ermB gene. Among the 330 C. difficile strains, 324 (98.2\%) revealed resistance to ciprofloxacin. Resistance to both gatifloxacin and moxifloxacin was found in $134(40.6 \%)$ and $134(40.6 \%)$ isolates from $\mathrm{H} 1$ and $\mathrm{H} 2$. Among strains isolated in $\mathrm{H} 1$ and $\mathrm{H} 2,72.0$ and $74.4 \%$ were resistant to imipenem, respectively, and $\sim 23 \%$ (76 isolates) were resistant to tetracycline in both hospitals. Resistance to imipenem (MICs $\geqslant 16 \mathrm{mg} \mathrm{l}^{-1}$ ) was observed among all the $\mathrm{CDT}^{+}$C. difficile strains belonging to ribotypes 023,027 and 045. Of the $\mathrm{A}^{-} \mathrm{B}^{+} \mathrm{CDT}^{-}$C. difficile strains (PCR ribotype 017), $86.8 \%$ were resistant to imipenem. Only one $c d t A /$ $c d t B$-positive isolate belonging to PCR ribotype 027 (in $\mathrm{H} 2$ ) was found; this strain was resistant to erythromycin

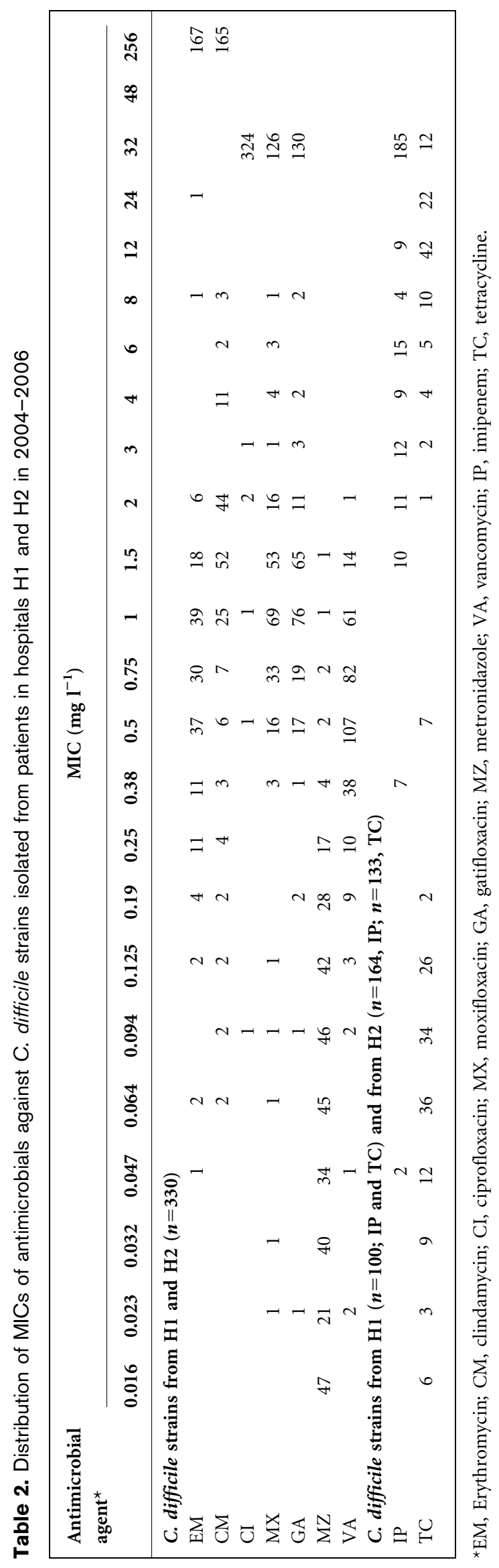


Table 3. Summary of MICs ( $\mathrm{mg} \mathrm{I}^{-1}$ ) of antimicrobial agents against $330 \mathrm{C}$. difficile strains isolated from adult patients with diarrhoea in two university hospitals $(\mathrm{H} 1$ and $\mathrm{H} 2)$ between 2004 and 2006

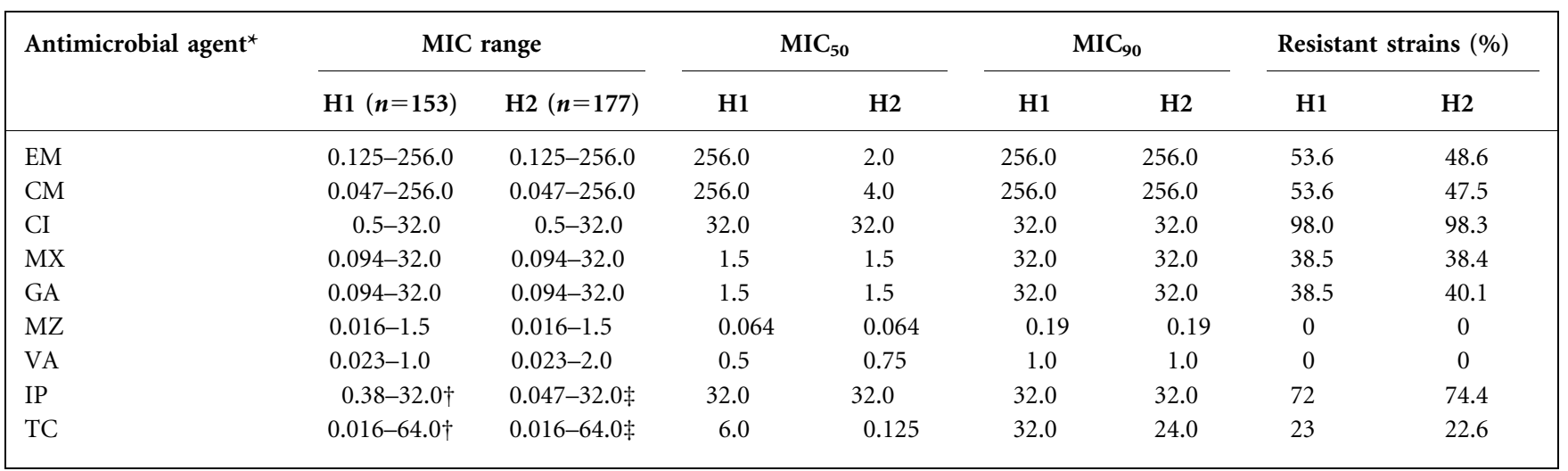

${ }^{\star}$ EM, Erythromycin; CM, clindamycin; CI, ciprofloxacin; MX, moxifloxacin; GA, gatifloxacin; MZ, metronidazole; VA, vancomycin; IP, imipenem; TC, tetracycline.

$\dagger$ The total number of isolates analysed for IP and TC resistance was 100 .

¥The total number of isolates analysed for IP resistance was 164 and for TC resistance was 133 .

and clindamycin and also to moxifloxacin and gatifloxacin. Multidrug resistance to erythromycin, clindamycin, ciprofloxacin, gatifloxacin and moxifloxacin was detected in 34.6 and $33.8 \%$ of $C$. difficile strains in $\mathrm{H} 1$ and $\mathrm{H} 2$, respectively.

\section{DISCUSSION}

In a previous study conducted between 2002 and 2003 in Poland, we analysed 79 C. difficile strains isolated over a 2year period from 785 adult patients with antibioticassociated diarrhoea hospitalized in one university hospital in Warsaw (Pituch et al., 2006). Among the strains investigated in that study, $44.3 \%$ were $\mathrm{A}^{+} \mathrm{B}^{+} \mathrm{CDT}^{-}$, $45.5 \%$ were $\mathrm{A}^{-} \mathrm{B}^{+} \mathrm{CDT}^{-}, 1.3 \%$ were $\mathrm{A}^{+} \mathrm{B}^{+} \mathrm{CDT}^{+}$and $8.9 \%$ were $\mathrm{A}^{-} \mathrm{B}^{-} \mathrm{CDT}^{-}$(Pituch et al., 2006). During the 2year study period, one outbreak of CDI cases caused by a $C$. difficile PCR ribotype 017 strain occurred among 12 patients at the internal unit. The findings of the present study confirm the high prevalence of $\mathrm{A}^{-} \mathrm{B}^{+} \mathrm{CDT}^{-}$isolates in some hospitals in Warsaw and emphasize the significance of $\mathrm{A}^{-}$strains (Pituch et al., 2007). Outbreaks due to PCR ribotype 017 were also observed in the present survey at an internal unit (between January 2005 and May 2005 involving seven patients) and at a surgery unit (between February 2006 and March 2006 involving seven patients). Most $\mathrm{A}^{-} \mathrm{B}^{+}$C. difficile isolates belong to ribotype 017, which is found more frequently in Asia than in some other continents (Shin et al., 2008; Huang et al., 2009). However, outbreaks of PCR ribotype 017 have also been reported from other continents and PCR ribotype 017 has a tendency to persist for a long time in hospitals (Arvand et al., 2009; Goorhuis et al., 2009).

In the current study, an increase of $\mathrm{A}^{+} \mathrm{B}^{+} \mathrm{CDT}^{+}$isolates was observed from $1.3 \%$ in 2003 to $5.5 \%$ in 2006 . The
PCR ribotypes involved were $023(n=16)$ and $045(n=1)$. C. difficile PCR ribotype 023 is not frequently found and was present in only $3 \%$ of all isolates characterized in a recent pan-European survey (Bauer et al., 2011). A similar trend of an increase in $\mathrm{CDT}^{+}$C. difficile strains has been found in Hungary (Terhes et al., 2009) where an increase in $\mathrm{A}^{+} \mathrm{B}^{+} \mathrm{CDT}^{+}$isolates from $2.5 \%$ in $2002-2003$ to $6.7 \%$ in 2006-2007 was observed. Barbut et al. (2007) found a higher prevalence of $\mathrm{CDT}^{+}$C. difficile strains in a European surveillance in 2005. The prevalence of $\mathrm{A}^{-} \mathrm{B}^{+} \mathrm{CDT}^{-}$C. difficile strains in Europe was $6.2 \%$ in the same study.

Epidemiological surveys suggest a spread of $C$. difficile PCR ribotype 027 across North America and Europe (Kuijper et al., 2008). However, a recently completed pan-European surveillance study revealed that the prevalence of PCR ribotype 027 was only $5 \%$ and was restricted mainly to the UK (Bauer et al., 2011). In Poland, we found a $0.3 \%$ prevalence of ribotype 027 . Barbut et al. (2007) observed a low prevalence of PCR ribotype 027 of $6.2 \%$ in 2005 in a European survey.

The antibiotic susceptibility of 330 C. difficile strains was tested against nine antibiotics. All strains were susceptible to metronidazole and vancomycin (according to CLSI breakpoints). In a recent published study performed in the $\mathrm{UK}, 24.4 \%$ of $C$. difficile ribotype 001 isolates had reduced susceptibility to metronidazole of $\geqslant 6 \mathrm{mg} \mathrm{l}^{-1}$, measured by a spiral-gradient end-point screening method (Baines et al., 2008), although the MIC values remained below the CLSI breakpoint. Other reports from the UK also mention higher MIC values for metronidazole of $1-2 \mathrm{mg} \mathrm{l}^{-1}$ (Burns et al., 2007; Brazier et al., 2008). Clinical breakpoints of metronidazole have not yet been determined, although it is likely that the currently applied CLSI breakpoint of $32 \mathrm{mg}$ $1^{-1}$ is too high. Our observation of elevated MIC values for 
metronidazole could have implications in the clinical setting due to the poor penetration of metronidazole into the colon, and this needs further study.

We observed a high level of cross-resistance to erythromycin and clindamycin (MIC $\geqslant 256 \mathrm{mg} \mathrm{l}^{-1}$ ) in the present study. Resistance against clindamycin and erythromycin among Polish $\mathrm{A}^{-} \mathrm{B}^{+} \mathrm{CDT}^{-}$(PCR ribotype 017) C. difficile strains was very high $(91 \%)$ but not among $\mathrm{A}^{+} \mathrm{B}^{+} \mathrm{CDT}^{-}$ and $\mathrm{A}^{-} \mathrm{B}^{-} \mathrm{CDT}^{-}$strains (7 and $2.1 \%$, respectively), which confirmed our previous observations (Pituch et al., 2006, 2007). Ilchmann et al. (2010), in a study performed in Germany, documented a significant increase from 13.0 to $54.8 \%$ of erythromycin- and clindamycin-resistant $C$. difficile strains belonging to PCR ribotype 001 (Ilchmann et al., 2010). Rates of resistance to erythromycin, clindamycin and moxifloxacin among strains isolated in 2006-2008 in Hungary were 25, 27.5 and $25 \%$, respectively (Terhes et al., 2009).

In our study, resistance to newer fluoroquinolones was found in $38.9 \%$ of the isolates. Resistance to newer fluoroquinolones has been described not only in the hypervirulent strain 027 but also in other emerging PCR ribotypes circulating in hospital settings (Pituch et al., 2007; Spigaglia et al., 2010). In a European prospective study conducted in 2005, strains resistant to moxifloxacin represented $37.5 \%$ of all C. difficile clinical isolates and the majority of the fluoroquinolone-resistant isolates belonged to PCR ribotype 126 or 018 (Barbut et al., 2007). In our study, combined resistance to erythromycin, clindamycin, gatifloxacin and moxifloxacin was associated with isolates belonging to PCR ribotype 017. Thus, this multiresistant PCR ribotype 017 still dominates in our hospitals.

\section{ACKNOWLEDGEMENTS}

We thank Dr Jon S. Brazier for kindly providing control strains and for his cooperation.

\section{REFERENCES}

Arvand, M., Hauri, A. M., Zaiss, N. H., Witte, W. \& Bettge-Weller, G. (2009). Clostridium difficile ribotypes 001,017 , and 027 are associated with lethal C. difficile infection in Hesse, Germany. Euro Surveill 14, pii-19403.

Baines, S. D., O'Connor, R., Freeman, J., Fawley, W. N., Harmanus, C., Mastrantonio, P., Kuijper, E. J. \& Wilcox, M. H. (2008). Emergence of reduced susceptibility to metronidazole in Clostridium difficile. J Antimicrob Chemother 62, 1046-1052.

Barbut, F., Mastrantonio, P., Delmée, M., Brazier, J., Kuijper, E. \& Poxton, I. on behalf of the European Study Group on Clostridium difficile (ESGCD) (2007). Prospective study of Clostridium difficile infections in Europe with phenotypic and genotypic characterisation of the isolates. Clin Microbiol Infect 13, 1048-1057.

Bauer, M. P., Notermans, D. W., van Benthem, B. H. B., Brazier, J. S., Wilcox, M. H., Rupnik, M., Monnet, D. L., van Dissel, J. T. \& Kuijper, E. J. for the ECDIS Study Group (2011). Clostridium difficile infection in Europe: a hospital-based survey. Lancet 377, 63-73.
Brazier, J. S., Raybould, R., Patel, B., Duckworth, G., Pearson, A., Charlett, A., Duerden, B. I. \& the HPA Regional Microbiology Network (2008). Distribution and antimicrobial susceptibility patterns of Clostridium difficile PCR ribotypes in English hospitals, 2007-08. Euro Surveill 13, pii:19000.

Burns, P., Wooton, M., Hall, V., Brazier, J. S. \& Howe, R. (2007). Antimicrobial susceptibility of epidemic and nonepidemic strains of Clostridium difficile. In Abstracts of the 47th Annual Interscience Conference on Antimicrobial Agents and Chemotherapy, Chicago, IL, 17-20 September. Abstract C2-2046. Washington, DC: American Society for Microbiology.

Clements, A. C., Magalhães, R. J., Tatem, A. J., Paterson, D. L. \& Riley, T. V. (2010). Clostridium difficile PCR ribotype 027: assessing the risks of further worldwide spread. Lancet Infect Dis 10, 395-404.

CLSI (2007). Methods for Antimicrobial Susceptibility Testing of Anaerobic Bacteria, 7th edn. Approved Standard. M11-A7. Wayne, PA: Clinical and Laboratory Standards Institute.

Freeman, J., Bauer, M. P., Baines, S. D., Corver, J., Fawley, W. N., Goorhuis, B., Kuijper, E. J. \& Wilcox, M. H. (2010). The changing epidemiology of Clostridium difficile infections. Clin Microbiol Rev 23, 529-549.

Goorhuis, A., Legaria, M. C., van den Berg, R. J., Harmanus, C., Klaassen, C. H., Brazier, J. S., Lumelsky, G. \& Kuijper, E. J. (2009). Application of multiple-locus variable-number tandem-repeat analysis to determine clonal spread of toxin A-negative Clostridium difficile in a general hospital in Buenos Aires, Argentina. Clin Microbiol Infect 15, 1080-1086.

Huang, H., Fang, H., Weintraub, A. \& Nord, C. E. (2009). Distinct ribotypes and rates of antimicrobial drug resistance in Clostridium difficile from Shanghai and Stockholm. Clin Microbiol Infect 15, 11701173.

Ilchmann, C., Zaiss, N. H., Speicher, A., Christner, M., Ackermann, G. \& Rohde, H. (2010). Comparison of resistance against erythromycin and moxifloxacin, presence of binary toxin gene and PCR ribotypes in Clostridium difficile isolates from 1990 and 2008. Eur J Clin Microbiol Infect Dis 29, 1571-1573.

Johnson, S., Samore, M. H., Farrow, K. A., Killgore, G. E., Tenover, F. C., Lyras, D., Rood, J. I., DeGirolami, P., Baltch, A. L. \& other authors (1999). Epidemics of diarrhea caused by a clindamycinresistant strain of Clostridium difficile in four hospitals. N Engl J Med 341, 1645-1651.

Kato, H., Kato, N., Watanabe, K., Iwai, N., Nakamura, H., Yamamoto, T., Suzuki, K., Kim, S.-M., Chong, Y. \& Wasito, E. B. (1998). Identification of toxin A-negative, toxin B-positive Clostridium difficile by PCR. J Clin Microbiol 36, 2178-2182.

Kuijper, E. J., Barbut, F., Brazier, J. S., Kleinkauf, N., Eckmanns, T., Lambert, M. L., Drudy, D., Fitzpatrick, F., Wiuff, C. \& other authors (2008). Update of Clostridium difficile infection due to PCR ribotype 027 in Europe, 2008. Euro Surveill 13, pii:18942.

Loo, V. G., Poirier, L., Miller, M. A., Oughton, M., Libman, M. D., Michaud, S., Bourgault, A. M., Nguyen, T., Frenette, C. \& other authors (2005). A predominantly clonal multi-institutional outbreak of Clostridium difficile-associated diarrhea with high morbidity and mortality. N Engl J Med 353, 2442-2449.

McDonald, L. C., Killgore, G. E., Thompson, A., Owens, R. C., Jr, Kazakova, S. V., Sambol, S. P., Johnson, S. \& Gerding, D. N. (2005). An epidemic, toxin gene-variant strain of Clostridium difficile. $N$ Engl J Med 353, 2433-2441.

Peláez, T., Alcalá, L., Alonso, R., Rodríguez-Créixems, M., GarcíaLechuz, J. M. \& Bouza, E. (2002). Reassessment of Clostridium difficile susceptibility to metronidazole and vancomycin. Antimicrob Agents Chemother 46, 1647-1650. 
Pituch, H., Brazier, J. S., Obuch-Woszczatyński, P., Wultańska, D., Meisel-Mikołajczyk, F. \& kuczak, M. (2006). Prevalence and association of PCR ribotypes of Clostridium difficile isolated from symptomatic patients from Warsaw with macrolide-lincosamidestreptogramin B $\left(\mathrm{MLS}_{\mathrm{B}}\right)$ type resistance. J Med Microbiol 55, 207-213.

Pituch, H., van Leeuwen, W., Maquelin, K., Wultańska, D., ObuchWoszczatyński, P., Nurzyńska, G., Kato, H., Reijans, M., MeiselMikolajczyk, F. \& other authors (2007). Toxin profiles and resistances to macrolides and newer fluoroquinolones as epidemicity determinants of clinical isolates of Clostridium difficile from Warsaw, Poland. J Clin Microbiol 45, 1607-1610.

Schwan, C., Stecher, B., Tzivelekidis, T., van Ham, M., Rohde, M., Hardt, W. D., Wehland, J. \& Aktories, K. (2009). Clostridium difficile toxin CDT induces formation of microtubule-based protrusions and increases adherence of bacteria. PLoS Pathog 5, e1000626.

Shin, B.-M., Kuak, E. Y., Yoo, H. M., Kim, E. C., Lee, K., Kang, J.-O., Whang, D. H. \& Shin, J.-H. (2008). Multicentre study of the prevalence of toxigenic Clostridium difficile in Korea: results of a retrospective study 2000-2005. J Med Microbiol 57, 697-701.
Spigaglia, P. \& Mastrantonio, P. (2002). Molecular analysis of the pathogenicity locus and polymorphism in the putative negative regulator of toxin production (TcdC) among Clostridium difficile clinical isolates. J Clin Microbiol 40, 3470-3475.

Spigaglia, P., Barbanti, F., Dionisi, A. M. \& Mastrantonio, P. (2010). Clostridium difficile isolates resistant to fluoroquinolones in Italy: emergence of PCR ribotype 018. J Clin Microbiol 48, 2892-2896.

Stubbs, S. L., Brazier, J. S., O'Neill, G. L. \& Duerden, B. I. (1999). PCR targeted to the 16S-23S rRNA gene intergenic spacer region of Clostridium difficile and construction of a library consisting of 116 different PCR ribotypes. J Clin Microbiol 37, 461-463.

Stubbs, S. L., Rupnik, M., Gibert, M., Brazier, J., Duerden, B. \& Popoff, M. (2000). Production of actin-specific ADP-ribosyltransferase (binary toxin) by strains of Clostridium difficile. FEMS Microbiol Lett 186, 307-312.

Terhes, G., Urbán, E., Sóki, J., Szikra, L., Konkoly-Thege, M., Vollain, M. \& Nagy, E. (2009). Assessment of changes in the epidemiology of Clostridium difficile isolated from diarrheal patients in Hungary. Anaerobe 15, 237-240. 